\section{Leveraging a Service Experience into a Course- Based Undergraduate Research Experience in an Introductory Geology Classroom}

Kaatje J. van der Hoeven Kraft and Karen M. Kortz

Whatcom Community College/Community College of Rhode Island,

kkraft@whatcom.edu

\section{doi: $10.18833 / \mathrm{spur} / 4 / 3 / 2$}

Whatcom Community College is a small, suburban public college situated near a large agricultural region. A local, nonprofit, organic farm (Growing Veterans n.d.) sought to partner with the institution in a service opportunity examining its soil health. The outcome was a course-based undergraduate research experience (CURE) for students in an introductory environmental geology course for nonmajors.

During a field trip to the farm early in the quarter, the farmers shared their current seasonal growing challenges. The farmers, who were experimenting with different kinds of cover crops, weeding methods, and plant rotations, wished to determine how these practices affected soil health. Student research compared the results of simple soil tests by field or over time. For example, groups of students examined the relationship among elements such as nitrate, $\mathrm{pH}$, earthworm concentration, soil infiltration, and soil bulk density as they compared different types of cover crops to noncovered areas. This partnership has operated since 2014, and data have accrued to support the farm's practice decisions such as employing specific cover crops to maintain soil health. Each year, students enter the raw data results from their research projects into a Google spreadsheet. This allows students to compare their results to those from previous years. As part of the CURE, students present their findings in a formal, academic-style poster session, to which the farmers, faculty, and staff are invited to attend. This poster session is in lieu of a final exam as a celebration of learning. The research posters and raw data are available for the farmers to reference throughout the year, which are used to make planting decisions.

Students completed a survey as part of their experience (Kortz and van der Hoeven Kraft 2016) in which they were asked three open-ended questions about how they benefited, how the project matched what they expected, and how their ideas about science changed. The responses captured similarities to the benefits and challenges described by Kortz and van der Hoeven Kraft (2016) such as an increased appreciation of science and scientists as well as more confidence in themselves. As one student wrote, "[I] gained confidence and experience in working with a team.
And confidence in my science skills." In addition, as this CURE was performing a service for a local organic farm, students also described the benefit of feeling like their work contributed to something greater beyond their own college experience. For example, as one student noted, "This was a different type of project w[h]ere you get to visit a place and try to help fix problems. It helps you get more involved and is more fun." Students benefited from this learning experience, and the farm receives ongoing consultation that informs its practices.

\section{References}

Growing Veterans. n.d. "A Place for Growing Food, Community, \& Each Other.” Accessed March 19, 2021. https://growingveterans.org/

Kortz, Karen M., and Kaatje J. van der Hoeven Kraft. 2016. "Geoscience Education Research Project: Student Benefits and Effective Design of a Course-Based Undergraduate Research Experience." Journal of Geoscience Education 64(1): 24-36. doi: $10.5408 / 15-11.1$

\section{Community College Ceramics and Student Research: Cooperative Work Experience Projects in the Arts}

Amiko Matsuo

South Seattle College, amiko.matsuo@seattlecolleges.edu

doi: $10.18833 /$ spur/4/3/3

Allan Hancock College is a California public community college located in northern Santa Barbara County, serving 11,500 students per semester. For the past three semesters in the Fine Arts Program, student researchers have been sampling, researching, and firing natural clay deposits found in the campus region. Students research local clays by firing them at various temperatures and adding variable fluxes to experiment with eutectic melting points. In 2020, a collaboration began with the California Department of Conservation. The Mineral Resources Program will provide resources for students to research the geological lifecycle of kaolins, gain an understanding of how clays are mined, and learn about other historical contexts of the region (brick-making factories, etc.). Amiko Matsuo, a faculty member in the college's 3D Fine Arts Program, worked with engineering geologist Greg Marquis to pilot a cooperative work experience (CWE) project to develop a model outreach/interdisciplinary curricular guide for the Minerals Resources Program.

This student research emerges from an effort to develop cross-disciplinary student research opportunities through the structure of internships. Matsuo worked with the 